\title{
Kecurangan pelaporan keuangan organisasi kemahasiswaan: perspektif crowe's fraud pentagon theory
}

\author{
Sunaryo ${ }^{1}$, Helianti Utami ${ }^{1}$ \\ ${ }^{1}$ Universitas Negeri Malang, Jl. Semarang No. 5 Malang, Indonesia
}

\begin{abstract}
Diterima: 22 Agustus 2020

Direvisi: 15 Juni 2020

Disetujui: 15 Juni 2020

Korespondensi:

Helianti Utami

helianti.utami.fe@um.ac.id

DOI:

http://dx.doi.org/10.17977/ um004v8i12021p51
\end{abstract}

\begin{abstract}
This study aims to investigate the practice of fraudulent accountability reports on Student Organization at State University $\mathrm{X}$ based on the perspective of fraud pentagon theory. This research used qualitative methods with a case study approach. The type of case study was multiple-case conducted on Student Organizations at State University X. Data were obtained through interviews, observations, and documentation of relevant data related to Student Organizations' financial reporting practices . The data was then analyzed by the fraud pentagon theory. The research findings indicate that the practice of public fraud was caused by elements of the pentagon fraud. There are similarities and differences in the types of pentagon fraud elements encountered by the management committee. This is due to the existence of different policies in each community in a campus.
\end{abstract}

Keywords: Fraud; Student Organization; Fraud pentagon theory

\begin{abstract}
Abstrak
Penelitian ini memiliki tujuan untuk mengetahui praktik kecurangan laporan pertanggungjawaban organisasi kemahasiswaan di Universitas Negeri X jika ditinjau dari perspektif fraud pentagon theory. Penelitian ini menggunakan metode kualitatif dengan pendekatan studi kasus. Jenis studi kasus yang digunakan adalah multi kasus yang dilakukan pada organisasi kemahasiswaan di Universitas Negeri X. Data diperoleh melalui wawancara, observasi dan, dokumentasi data yang relevan terkait dengan praktik pelaporan keuangan organisasi kemahasiswaan. Data kemudian dianalisis dengan fraud pentagon theory. Hasil temuan penelitian menunjukkan bahwa praktik kecurangan organisasi kemahasiswaan disebabkan oleh elemen-elemen fraud pentagon. Terdapat persamaan dan perbedaan jenis elemen fraud pentagon yang dihadapi pengurus organisasi kemahasiswaan. Hal ini disebabkan adanya kebijakan yang berbeda di masing-masing organisasi kemahasiswaan dalam satu kampus.

Kata Kunci: Kecurangan; Organisasi Kemahasiswaan; Fraud pentagon theory
\end{abstract}

\section{PENDAHULUAN}

Mahasiswa berperan sebagai agent of change yang diharapkan mampu memberikan perubahan ke arah yang lebih baik bagi bangsa dengan menciptakan dan mewujudkan ide-ide kreatif, inovatif dan inspiratif di bidang pendidikan, teknologi, infomasi dan bidang lainnya. Sehubungan dengan itu, mahasiswa diberikan fasilitas akademik dan non-akademik selama menuntut ilmu dan pengalaman di perguruan tinggi untuk melatih kemampuan hard-skill dan soft-skill. Organisasi Kemahasiswaan (Ormawa) di tingkat universitas, fakultas dan jurusan meliputi Badan Eksekutif Mahasiswa (BEM), Unit Kegiatan Mahasiswa (UKM), dan Organisasi Pemerintahan Mahasiswa (OPM). Ormawa merupakan wadah yang disediakan oleh perguruan tinggi untuk mewujudkan kreativitas mahasiswa dalam berbagai bentuk kegiatan dan praktik soft-skill. Melalui Ormawa, mahasiswa diharapkan mampu membentuk softskillyang bersifat positif seperti: kerjasama; keberanian menyampaikan pendapat; perasaan menghargai pendapat orang lain; dan tanggungjawab. Salah satu bentuk pertanggungjawaban yang harus dilakukan oleh Ormawa adalah pertanggungjawaban keuangan atas setiap kegiatan yang dilakukan. Pengurus Ormawa diharapkan dapat menyusun laporan pertanggungjawaban yang jujur dan dapat dipercaya. Namun, beberapa penelitian terdahulu menunjukkan bahwa terdapat penyimpangan dalam pelaporan keuangan kegiatan Ormawa pada beberapa perguruan tinggi. Bentuk penyimpangan beragam seperti menyalahgunakan aset, manipulasi laporan anggaran, manipulasi laporan pertanggungjawaban (Salsabil et al., 2019), serta memalsukan dokumen, penggelapan (Puspitasari et al., 2015). 
Praktik penyimpangan yang dilakukan oleh pengurus Ormawa termasuk dalam kategori fraud (kecurangan) yang merupakan kecurangan berhubungan dengan penyimpangan dan perbuatan melanggar hukum (illegal act) dan dilakukan dengan sengaja untuk menipu atau memberikan informasi yang salah (mislead) kepada pihak lain (Karyono, 2013). Disamping itu, Karyono mengklasifikasikan fraud ke dalam 4 kategori yang meliputi kecurangan laporan keuangan, penyalahgunaan asset, korupsi, dan kecurangan yang berkaitan dengan komputer (Karyono, 2013).

Free (2015) menyebutkan bahwa Fraud triangle merupakan rerangka (framework) dominan sehubungan dengan penipuan. Hal ini dapat diketahui dari penyebutan Fraud triangle pada beberapa standar auditing profesional di seluruh dunia, seperti IAASB pada tahun 2009, PCAOB pada tahun 2005, SAS No. 99 (USA), ASA 240 (Australia) dan ISA 240 (Standar Audit Internasional). Fraud triangle mempertimbangkan keberadaan 3 faktor yang mendorong terjadinya fraud yaitu: tekanan atau insentif yang memberikan motif untuk melakukan penipuan, kesempatan untuk melakukan penipuan, dan sikap yang memungkinkan individu melakukan kecurangan atau kemampuan merasionalisasi kecurangan (Free, 2015).

Fraud triangle Theory kemudian dikembangkan oleh Wolfe \& Hermanson (2004) menjadi Fraud Diamond Theory dengan menambah satu elemen yaitu "kemampuan" (Avortri \& Agbanyo, 2020). Kemampuan memungkinkan orang sering melakukan fraud (Abdullahi \& Mansor, 2015). Selanjutnya, Marks \& Jonathan (2012) (partner Kantor Akuntan Publik dan konsultan Crowe Horwarth LLP di Amerika Serikat) mencetuskan Crowe's Fraud pentagon theory pada tahun 2012. Crowe's Fraud pentagon theory merupakan pengembangan dari Fraud triangle Theory dengan menambahkan unsur "kompetensi" dan "kesombongan" (Muhsin et al., 2018). Kompetensi pada Fraud pentagon theory memiliki maksud yang sama dengan kemampuan pada Fraud Diamond Theory.

Kemampuan (competence) adalah suatu kemampuan yang dimiliki seseorang untuk menciptakan keinginan melakukan fraud menjadi tindakan nyata (Danuta, 2017). Kesombongan (arrogance) diidentifikasikan sebagai sikap superioritas dan merasa berhak atau keserakahan sebagai bagian dari seseorang yang percaya bahwa pengendalian internal tidak berlaku terhadapnya (Danuta, 2017). Keberadaan 5 unsur dari Fraud Pentagon diyakini Crowe dapat memicu keinginan seseorang untuk melakukan fraud di organisasi. Fraud merupakan penyimpangan dan perbuatan melanggar hukum yang dilakukan secara sengaja untuk tujuan tertentu yang secara langsung atau tidak langsung dapat merugikan orang lain (Karyono, 2013).

Ormawa merupakan salah satu bentuk fasilitas non-akademik yang disediakan dan didukung oleh perguruan tinggi. Ormawa memiliki tugas untuk merencanakan, melaksanakan, dan mengembangkan kegiatan organisasi yang bersifat penalaran, minat dan kegemaran, kesejahteraan, dan minat khusus sesuai dengan tugas dan tanggungjawab. Pelaksanaan kegiatan Ormawa yang berdasarkan progam kerja yang mendapatkan pendanaan dari pihak kampus sehingga pengurus Ormawa memiliki kewajiban untuk memberikan laporan pertanggungjawaban dalam bentuk laporan keuangan sederhana sebagai bentuk tanggung jawab kepada pihak pemberi dana.

Penelitian ini memiliki tujuan untuk mendapatkan temuan praktik fraud pelaporan keuangan pada Ormawa di perguruan tinggi negeri X ditinjau dari sudut pandang Crowe's Fraud pentagon theory. Penelitian ini dilakukan dengan beberapa pengembangan dari penelitian sebelumnya. Penelitian yang dilakukan oleh Salsabil et al. (2019) dan Puspitasari et al. (2015) berfokus pada 2 sudut pandang yaitu Ormawa dan pemberi dana (universitas/fakultas) untuk mendapatkan pemahaman yang lebih menyeluruh mengenai fenomena yang terjadi. Puspitasari et al. (2015); Tiffani et. al. (2015); Setiawan et al.(2013); dan Skousen et al. (2009) menggunakan fraud triangle theory. Penelitian yang berfokus pada fraud dalam pelaporan keuangan suatu perusahaan lebih banyak menggunakan jenis pendekatan kuantitatif (Skousen et al., 2009; Tiffani et al., 2015). Penelitian Salsabil et al. (2019) menggunakan pendekatan kualitatif deskriptif. Penelitian yang dilakukan oleh Puspitasari et al. (2015) berfokus pada fraud Ormawa dengan menggunakan pendekatan kualitatif single-case study yang hanya menggunakan satu organisasi kemahasiswaan. Penelitian ini menggunakan pendekatan kualitatif jenis multi-cases study yang dilakukan pada dua Ormawa. Penelitian ini menggunakan Fraud pentagon theory karena teori ini telah menyempurnakan teori fraud sebelumnya dengan memperhatikan kondisi saat ini. Disamping itu, pengambilan topik penelitian ini berdasarkan hasil observasi yang menunjukkan adanya beberapa praktik yang mengarah pada bentuk-bentuk kecurangan dalam Ormawa.

\section{METODE}

Penelitian ini menggunakan pendekatan penelitian kualitatif. Penelitian kualitatif merupakan penelitian yang bermaksud untuk memahami fenomena tentang apa yang dialami oleh subjek penelitian misalnya perilaku, persepsi, motivasi, tindakan, dan aspek lain secara holistik dengan 
cara deskripsi dalam bentuk kata-kata dan bahasa pada suatu konteks khusus yang alamiah dengan memanfaatkan berbagai metode alamiah (Moleong, 2004). Pendekatan kualitatif dipandang tepat untuk digunakan dalam penelitian ini karena penelitian ini bermaksud memperoleh pemahaman yang mendalam mengenai fenomena yang terjadi dengan latar alamiah terkait dengan praktik pelaporan keuangan Ormawa di Universitas Negeri X.

Jenis penelitian ini menggunakan jenis studi kasus. Secara umum, studi kasus lebih sesuai untuk penelitian yang berfokus pada "how" atau "why". Studi kasus juga sesuai untuk kondisi penelitian yang memiliki sedikit peluang untuk mengendalikan peristiwa-peristiwa yang diselidikidan berfokus pada kasus kontemporer (masa kini) di dalam kehidupan nyata (Yin, 2009). Penggunaan studi kasus memungkinkan upaya untuk memperdalam penelitian kasus atau fenomena yang kontemporer dimana penelitian dapat digunakan untuk mencari suatu realita yang tersembunyi terkait bagaimana praktik kecurangan pelaporan keuangan Ormawa di Universitas Negeri X. Penelitian ini menggunakan multi case studies dengan melibatkan dua Ormawa yaitu Ormawa Y pada tingkat universitas dan Ormawa $\mathrm{Z}$ pada tingkat fakultas di Perguruan Tinggi Negeri X.

Penelitian ini menggunakan triangulasi metode penelitian dalam mengumpulkan data. Data penelitian ini merupakan data primer yang diperoleh dari wawancara tatap muka semi-terstruktur dan observasi kepada aktivitas informan. Informan kunci penelitian ini terdiri atas pengurus Ormawa Y dan Ormawa $\mathrm{Z}$ yang meliputi ketua, wakil ketua, sekretaris, dan bendahara. Informan tersebut merupakan pihak-pihak yang memiliki peran penting dalam pengambilan keputusan pada pelaporan keuangan Ormawa. Selain itu, konfimasi ke pihak pemberi dana juga dilakukan dalam penelitian ini untuk mendapatkan pemahaman yang lebih menyeluruh terkait dengan pelaporan keuangan Ormawa. Informan pemberi dana meliputi pihak sub-bagian kemahasiswaan yaitu Kasubbag Kemahasiswaan tingkat fakultas dan universitas. Data sekunder juga digunakan dalam penelitian yang mencakup dokumentasi berupa arsip, foto, dan dokumen lain yang relevan dengan penelitian. Analisis data mengacu pada Miles \& Huberman (1992) yang meliputi tiga tahapan yaitu reduksi data, penyajian data, dan penarikan kesimpulan (verifikasi). Tahapan tersebut akan diterapkan untuk setiap kasus tunggal. Setelah itu, analisis multi kasus akan dilakukan dengan cara membandingkan dan memadukan temuan yang diperoleh pada tahap analisis kasus tunggal.

\section{HASIL DAN PEMBAHASAN}

Ormawa Y merupakan UKM bidang penalaran pada tingkat universitas, sedangkan Ormawa $\mathrm{Z}$ merupakan UKM bidang seni olah suara pada tingkat fakultas. Dalam melaksanakan program kerja, pengurus Ormawa Y dan Ormawa Z harus mengikuti 3 prosedur yang sudah ditentukan, yaitu: 1) mendapatkan izin pelaksanaan kegiatan dan persetujuan pendanaan dengan mengajukan proposal kegiatan; 2) melaksanakan kegiatan; 3) menyerahkan Laporan Pertanggungjawaban (LPJ) pelaksanaan program kerja. Pengurus Ormawa menghadapi beberapa kendala ketika melaksanakan prosedur pelaporan mulai dari proses pengajuan proposal sampai pengajuan LPJ ke pihak kampus. Upaya yang dilakukan oleh pengurus Ormawa untuk mengatasi kendala-kendala tersebut adalah dengan melakukan beberapa trik atau kecurangan. Pada bagian ini, penelitian ini akan memaparkan praktik kecurangan yang dilakukan Ormawa Y dan Ormawa Z dalam pelaporan keuangan aktivitas/ program kerja. Selanjutnya, penelitian akan menggunakan perspektif Fraud Pentagon Teory untuk mengulas praktik kecurangan tersebut.

\section{Praktik Kecurangan Pelaporan Keuangan Organisasi Kemahasiswaan}

Bentuk kecurangan pelaporan keuangan Ormawa meliputi pemalsuan tandatangan, pembuatan nota fiktif, penyajian angka terlalu tinggi (mark up) di anggaran, dan pembuatan stempel palsu.

\section{a. Pemalsuan Tanda Tangan}

Hasil wawancara menunjukkan bahwa pengurus Ormawa Y menghadapi kesulitan untuk bisa secepatnya menemui pendamping untuk mendapatkan tanda tangan. Selain itu, terdapat permintaan revisi proposal usulan kegiatan Ormawa Y dari pendamping. Kedua hal tersebut berdampak pada lamanya waktu yang diperlukan sebelum pengurus Ormawa Y untuk dapat menyerahkan proposal kegiatan ke tahapan berikutnya yaitu ke universitas. Berikut ini merupakan hasil wawancara dengan ketua Ormawa Y:

"Kalo masalah prosedural begitu kita lebih terkendala pada waktu sih mas, kadang gak ketemu sama pendamping, nunggu ditandatangani, kadang juga ada revisi dari pendamping juga. Ini dibenerin, ini dibenerin gitu. Kita ya balik lagi buat ngerevisi". 
Selain itu, diperlukan waktu yang cukup lama untuk menyelesaikan birokrasi di tingkat universitas terkait dengan pengajuan ijin kegiatan. Hal tersebut memotivasi pengurus Ormawa Y untuk melakukan pemalsuan tanda tangan pendamping sebagai solusi untuk mempercepat proses pengajuan proposal kegiatan ke jenjang tingkat universitas.

Demikian juga dengan Ormawa $\mathrm{Z}$ yang berada di bawah koordinasi fakultas dimana pengurus Ormawa harus melalui prosedur yang berlapis dan memerlukan waktu yang lama untuk mendapatkan ijin dan pendanaan untuk melaksanakan kegiatan Ormawa. Prosedur tersebut meliputi otorisasi ketua BEM, otorisasi pendamping sampai dengan otorisasi pada tingkat fakultas, persetujuan kegiatan dari Wakil Dekan 3 (bidang kemahasiswaan) dan Wakil Dekan 2 (bidang keuangan). Namun demikian, pemalsuan tanda tangan pendamping tidak ditemukan pada Ormawa $\mathrm{Z}$ dikarenakan pendamping cenderung mudah untuk ditemui.

Kasus lain yang ditemukan terkait dengan pemalsuan tanda tangan adalah pengurus Ormawa $\mathrm{Y}$ dan Ormawa $\mathrm{Z}$ yang melakukan pemalsuan tanda tangan presensi untuk mengisi tanda tangan peserta dan panitia kegiatan yang tidak hadir atau lupa untuk tanda tangan. Tanda tangan fiktif dilakukan untuk melengkapi presensi agar jumlah uang dapat dicairkan secara penuh. Hal ini dikarenakan dana operasional Ormawa Y dan Ormawa Z yang disediakan oleh universitas dan fakultas baru dapat dicairkan jika pengurus Ormawa Y dan Ormawa Z sudah melakukan program kerja dan menyelesaikan LPJ dan Surat Pertanggungjawaban (SPJ) kegiatan yang dilakukan. Hal tersebut seperti yang diungkapkan oleh wakil ketua Ormawa Y:

“...kita baru dapat uangnya kalo udah selesai LPJ dan SPJ an”.

Konfirmasi yang dilakukan peneliti dengan petugas bagian kemahasiswaan pada tingkat fakultas mengenai pencairan dana dengan jumlah minim pada awal kegiatan agar Ormawa tidak terlambat dalam menyusun LPJ.

“...kalo itu tergantung kebijakan di unit keuangan. Biasanya itu gak 100\% karena Ormawa

kadang-kadang kalo diberi 100\% urusan laporan molor, maka disisakan berapa persen.

Akan dibayarkan full kalo proses laporan sudah selesai".

Pelaksanaan pogram kerja Ormawa Y dan Ormaya Z selama ini didukung dengan sumber dana Ormawa yang lain, seperti dana yang dikumpulkan dari kas anggota, dana usaha Ormawa dari penjualan kue-kue yang dititipkan di kantin-kantin fakultas, serta dana dari sponsor jika ada. Oleh karena itu, kelengkapan presensi ini sangat diperlukan sebagai bukti pembelian konsumsi peserta dan panitia sehingga dapat digunakan sebagai syarat untuk mendapatkan pencairan dana operasional yang bersumber dari universitas. Berikut hasil wawancara dengan sekretaris Ormawa Y terkait dengan hal itu:

"Kadang kita bermasalah di presensi mas, kita nyukup nyukupin gitu lo. Misal kita dana 1 juta, sedangkan sebenarnya konsumsi cuma habis 900 ribu. Jadi kita kek nyukupnyukupin dengan buat presensi lagi agar bisa pas 1 juta gitu. Akhirnya kita tanda tangan sendiri sampek banyak itu mas".

\section{b. Pembuatan Nota Fiktif}

Pengurus Ormawa $\mathrm{Y}$ dan $\mathrm{Z}$ sering menghadapi masalah terkait dengan bukti transaksi pembelian (nota) pada saat penyusunan LPJ. Proses pencairan dana akan terhambat jika terdapat nota hilang atau nota dengan informasi tidak lengkap seperti: nota tanpa identitas toko, nota tanpa stempel toko, serta beberapa nota yang tidak dapat digunakan dalam LPJ. Berikut hasil wawancara dengan bendahara Ormawa Z:

"Kendala bisa juga dari bukti LPJ mas, kan ada beberapa nota yang gak bisa di-LPJ-kan,

kek transport dan sewa gedung itu gak bisa di-LPJ-kan".

Bendahara menyampaikan bahwa pengeluaran Ormawa yang tidak bisa digunakan dalam LPJ seperti sewa transport dan sewa gedung, tidak mendapat alokasi anggaran dari universitas. Oleh karena itu, pengurus Ormawa berinisiatif untuk membebankan pengeluaran yang tidak bisa digunakan dalam LPJ ke bentuk pengeluaran lain yang bisa digunakan dalam LPJ dengan nota fiktif. Berikut ini hasil wawancara dengan ketua Ormawa Y:

"Sebenernya uang ini kita gunain, tapi buktinya kita alihkan gitu lo".

Selain itu, pihak universitas meminta pengurus Ormawa untuk segera melaporkan LPJ kegiatan Ormawa sesegera mungkin. Hal tersebut memberikan beban tambahan bagi pengurus Ormawa seperti yang diungkapkan oleh kasubag kemahasiswaan Universitas X: 
"Kita juga dikejar waktu. Kalo sekarang sudah mengajukan proposal ya bulan depan mereka harus mengumpulkan SP’'.

Sehubungan dengan kondisi tersebut, pengurus Ormawa berinisiatif untuk membuat nota fiktif. Nota fiktif dibuat untuk melengkapi bukti transaksi yang hilang, bukti transaksi yang tidak dapat digunakan dalam LPJ, dan untuk memenuhi syarat nominal uang agar sesuai dengan jumlah dana yang didapat dari universitas. Nota hilang biasanya disebabkan karena penanggung jawab yang membeli barang atau konsumsi tidak langsung menyerahkan nota ke bendahara pelaksana. Disamping itu, bendahara pelaksana tidak selalu berada di UKM sehingga penanggungjawab harus membawa bukti transaksi terlebih dahulu. Hal tersebut yang menyebabkan bukti transaksi mudah hilang. Selain itu, terdapat beberapa toko yang tidak menyediakan nota dengan identitas yang jelas sehingga nota ini tidak dapat digunakan sebagai bukti transaksi untuk sebagai syarat LPJ. Kondisi tersebut diungkapkan oleh bendahara Ormawa Y:

"Kadang itu nota juga ada yang ketlisut mas, jadi kita nyari nota yang ketlisut mas, kalo gak gitu kita hubungi penanggungjawab yang beli, nanti habis berapa gitu.... Terus untuk kekurangan dananya kita bikin sendiri notanya .... kita biasanya minta nota kosong gitu".

Pernyataan tersebut didukung dengan behandara Ormawa $\mathrm{Z}$ yang menyebutkan:

"kita nota biasanya langsung minta ke toko nya dan kita juga minta nota kosong mas, ya nanti buat nambahi nominal yang kurang mas, biar pas jumlahnya mas".

LPJ yang diserahkan oleh pengurus Ormawa Y tidak diperiksa dengan cermat oleh petugas penerima LPJ di universitas. Pemeriksaan LPJ hanya sebatas terpenuhinya persyaratan administrasi, seperti susunan nota, kuitansi, dan urutan surat sesuai tanggal. Pemeriksaan LPJ tidak berfokus pada kewajaran jumlah nominal pada nota dan keaslian nota yang dilampirkan. Hal tersebut sesuai dengan pernyataan dari ketua Ormawa Y:

“Kalo memalsukan (nota) pernah mas, tapi ya gak pernah sih sampek kena (ketahuan)".

Kemudian, ketua umum Ormawa Y menyatakan:

"Dari pihak rektorat soalnya gak dicek terlalu ketat ya. Kebanyakan itu yang dicek itu keurutannya. Kalo dijumlah sih kek nya nggak mas. Nggak dicek pakek kalkulator sih. Yang dicek itu udah urut belum presensinya, kwitansinya, suratnya sama formatnya udah bener apa beluk kek gitu".

Terkait dengan pembuatan nota fiktif, pengurus Ormawa merasa hal tersebut wajar dilakukan dengan alasan sebagai berikut:

"Yang penting gak kelihatan nota palsu mas dan kita gak pakek untuk duitnya untuk kepentingan pribadi ya, itu juga untuk kepentingan UKM kok. Tahu sih mas, malah mereka itu 'ohh iya iya, gak papa mas sante' gitu. Malah dari pihak atas (kampus) itu nyaranin kita, biar mudah itu disuruh jadiin satu kwitansi aja. Jadi total konsumsi untuk LKMO 1 juta, biar pas sama yang di-acc".

Kondisi tersebut berbeda dengan pernyataan pihak fakultas yang menyatakan bahwa terdapat pemeriksaan atas LPJ Ormawa $\mathrm{Z}$ yang dilakukan oleh bagian keuangan. Bagian keuangan akan memeriksa kesesuaian bukti transaksi dengan ketentuan. Jika ditemukan bukti transaksi yang tidak sesuai ketentuan, maka LPJ akan dikembalikan pada pengurus Ormawa Z yang kemudian pengurus diminta untuk memperoleh bukti transaksi yang valid, seperti yang diutarakan sebagai berikut:

"Dengan tidak diterima itu kan berarti mencari sendiri. Buktinya cari lagi sesuai dengan riil pengeluaran”.

Jika pengurus Ormawa $\mathrm{Z}$ diketahui melakukan kecurangan, maka akan dilakukan unsur pembinaan kepada pengurus Ormawa.

“Tentunya ya ada, cuman kan gak dipublikasikan. Artinya apa? Kan harus ada unsur edukasi ke mereka. Kan mereka masih dalam proses belajar, salah bukan berarti fatal, ya nggak, kan bisa diulangi minta nota pembelian yang sesuai yang atau kwitansi yang resmi".

\section{c. Mark up Anggaran Kegiatan}

Prinsip Ormawa adalah "besar anggaran, kecil pengeluaran" dimana penyusunan proposal pengajuan dana kegiatan selalu melibatkan estimasi yang lebih tinggi dibandingkan dengan nilai sebenarnya. Hal tersebut seperti yang disampaikan oleh bendahara Ormawa Y sebagai berikut: 
"Nah waktu bikin proposal itukan kita pasti menaik-naikkan harganya, sedangkan saat eksekusi kita pasti cari harga yang pres atau kita memperkecil pengeluaran mas, jadi kita kek bikin nota palsu untuk mengenolkan saldonya itü".

Pengurus Ormawa Y dan Z memiliki alasan yang serupa untuk melakukan mark-up anggaran, seperti yang pernyataan sebagai berikut:

"Kalo itu sih, selama ini kita nggak takut ya mas, soalnya uangnya juga sudah digunakan dan sudah ada kesepakatan di accnya berapa. Kita dijatah Rp15 juta setahun, entah habis atau gak ya pokok pihak universitas ngasihnya segitu. Jadi kita ya ngepas-ngepasin biar Rp15 juta itu bisa habis mas. Eman kalo gak habis mas".

"Yang penting itu nanti kita maksimalkan 14 juta sekian tadi mas, kalo kurang pasti boleh ya mas, tapikan ya eman lah mas".

Selain alasan yang disampaikan seperti di atas, argumentasi lain adalah sebagai berikut:

"Ya itu emang udah dari tahun ke tahun kek gitu sih mas. Pastinya semua UKM juga melakukan hal yang sama ya mas, prinsipnya pasti sama, meminimalkan pengeluran dan memaksimalkan keuntungan mas. Dari praktiknya kitakan udah tahu sendiri mas, emang sejak dari dulu ketika kita pas jadi PI acara udah dikasih tahu gimana cara buat LPJan kek gitu."

"Ya kan itu kita gak 100\% salah sih mas. Kenapa? Soalnya kan itu ya hak kita untuk menggunakan uang itu. Toh uang yang didapat kita gunakan untuk proker kita"

Bendahara Ormawa Y menyatakan bahwa setiap kali Ormawa merancang anggaran dana kegiatan, terdapat mark-up anggaran. Realisasi anggaran Ormawa lebih kecil dibanding dengan anggaran yang telah diajukan. Contoh penerapan mark-up tersebut adalah pembuatan nota-nota tambahan untuk menyesuaikan dengan nominal yang disetujui pihak universitas. Upaya tersebut menyebabkan dana dari universitas dapat terserap penuh dan pihak Ormawa mendapatkan laba dari selisih antara anggaran dan realisasi. Laba tersebut akan menjadi uang kas Ormawa yang dapat digunakan untuk mendanai program kerja yang tidak dapat digunakan dalam LPJ, seperti perayaan ulang tahun Ormawa, rekreasi, dan kunjungan alumni. Hal tersebut sesuai dengan pernyataan bendahara Ormawa Y:

"Proker-proker kita ini banyak, ada lomba, kepelatihan yang tiap minggu 4 kali, terus belum lagi proker besar. Apalagi kalo proker A itu kita pasti minus mas. Kalo tahun lalu itu kira-kira kita minus 1 jt an mas, tapi kalo tahun ini kita gak sampek 500 ribu mas".

Ketua Ormawa Z menambahkan sebagai berikut:

"Soalnya kalo gak dimanipulasi mungkin kita bakal kebingungan mas. Wong yang dimanipulasi saja kita sering nambeli kok heheheh".

Anggaran yang diberikan oleh kampus tidak cukup untuk memenuhi kebutuhan pelaksanaan progam kerja yang banyak. Namun demikian, selain menyusun program kerja yang tidak realistis, pengurus Ormawa juga menetapkan target keuangan yang lebih tinggi dari kepengurusan sebelumnya. Hal tersebut sesuai dengan hasil wawancara berikut ini:

"Tahun ini dana taktis yang semula hanya 8 juta dinaikkan jadi 11 juta mas"

Dengan keterbatasan anggaran yang ada, pengurus Ormawa Y memiliki tanggung jawab untuk merealisasikan target keuangan yang telah ditetapkan. Namun, terdapat kebijakan yang berbeda untuk hal serupa pada Ormawa Z, seperti yang dinyatakan oleh ketua Ormawa Z berikut ini:

"Kita tidak menargetkan. Intinya, kegiatan bisa jalan gitu mas, jadi ya gak ada target berapa nominalnya".

\section{d. Pembuatan Stempel Palsu}

Praktik pelaporan keuangan organisasi kemahasiswaan yang mengarah pada tindak kecurangan lainnya adalah dengan adanya stempel palsu. Praktik ini dilatarbelakangi beberapa alasan. Alasan pertama karena kesibukan pengurus Ormawa Y di luar organisasi menyebabkan pengurus Ormawa sulit untuk meluangkan waktu untuk mendapatkan stempel asli dari toko. Upaya untuk mendapatkan stempel asli toko membutuhkan waktu sedangkan waktu untuk menyelesaikan LPJ sangat terbatas. Untuk mengatasi masalah tersebut, pengurus berinisiasi menggunakan stempel palsu seperti yang diungkapkan oleh bendahara Oramwa Y berikut ini: 
"Ya kek proposal tadi mas, molor molor gitu. Kesibukan orang masing-masing, tanda tangan, nunggu kuitansi terkumpul gitu".

Alasan kedua pembuatan stempel palsu adalah tidak semua nota yang diberikan oleh toko berstempel seperti yang disyaratkan oleh pihak universitas/fakultas. Untuk mengatasi masalah tersebut, pengurus Ormawa Y dan Ormawa Z menggunakan stempel palsu untuk keperluan SPJ dan kuitansi. Stempel ini dibuat pengurus Ormawa untuk memperlancar proses LPJ. Praktik nota palsu, bukti transaksi dan juga LPJ dapat dengan mudah diselesaikan dengan adanya stempel palsu ini. Hal tersebut diungkapkan oleh bendahara Ormawa Y dan bendahara Ormawa Z:

"Kita juga punya kuitansi sendiri sih mas, juga ada stempel beberapa, kek stempel makanan, fotokopian, percetakan, hahaha lengkaplah mas".

"Kita kan juga punya stempel-stempel buatan sendiri mas hehehe. Itu nanti kalo ada nota kosong ya bisa pakek itu. Kadang kita juga pinjem-pinjem ke Ormawa yang lain mas. Udah biasa mas seperti itu, dan semuanya udah tahu kok".

Pengurus Ormawa Y dan Ormawa Z menggunakan stempel palsu tersebut karena merasa hal tersebut sudah dilakukan oleh pengurus-pengurus Ormawa Y dan Ormawa Z sebelumnya dan juga dilakukan oleh UKM-UKM yang lain.

"Dan kita gak takut sih mas, ehh takut tapi ya cuman dikit, karenakan ya keadaan ya mas, dan inipun sudah biasa dilakukan oleh pengurus-pengurus sebelum kita. Kek gitu mas".

"Ya kita hanya sebatas taulah mas kalo UKM lain itu melakukan hal yang sama seperti kita, tapi kita tidak pernah sih sampek ikut campur urusan mereka".

\section{Praktik Pelaporan Keuangan Ormawa dalam Perspektif Fraud Pentagon Theory}

Crowe's Fraud pentagon theory menyatakan kecurangan terjadi karena adanya beberapa unsur pemicu, yaitu tekanan (pressure), kesempatan (opportunity), rasionalisasi (rationalization), kemampuan (competence), dan arogansi (arrogance) (Muhsin et al., 2018). Penelitian ini akan membahas praktik kecurangan pada Ormawa Y dan Ormawa Z dari perspektif teori Fraud Pentagon.

\section{a. Tekanan (Pressure)}

Data hasil wawancara, observasi, dan dokumentasi menunjukkan terdapat beberapa perbedaan dan persamaan kecurangan yang dilakukan oleh pengurus Ormawa Y dan Ormawa Z. Titik-titik kecurangan yang berbeda tersebut menunjukkan adanya perbedaan tekanan yang ditemukan pada kasus Ormawa Y dan Ormawa Z. Data menunjukkan bahwa Ormawa Y pada tataran universitas menghadapi lebih banyak tekanan daripada Ormawa $\mathrm{Z}$ pada tingkat fakultas. Berikut ini beberapa perbedaan titik-titik tekanan:

1) Pendamping kegiatan Ormawa $Y$ sulit untuk ditemui

Bentuk kecurangan yang berupa pemalsuan tanda tangan pendamping dilakukan oleh pengurus Ormawa Y dikarenakan adanya tekanan yang dirasakan bagi pengurus Ormawa Y. Tekanan tersebut yaitu kesulitan bertemu dengan pendamping kegiatan Ormawa, sementara Ormawa memiliki waktu yang terbatas. Kesulitan tersebut timbul karena Ormawa Y merupakan Ormawa tingkat universitas. Situasi tersebut memotivasi pengurus Ormawa Y untuk melakukan kecurangan dalam bentuk pemalsuan tanda tangan pendamping. Sedangkan pemalsuan tanda tangan tidak ditemukan di Ormawa Z. Hal tersebut dikarenakan Ormawa $\mathrm{Z}$ merupakan Ormawa tingkat fakultas dimana pertemuan dengan pendamping kegiatan Ormawa $\mathrm{Z}$ relatif lebih mudah.

2) Besar Pasak Daripada Tiang

Orwama Y menyusun banyak agenda kegiatan yang akan dilakukan oleh organisasi. Namun, agenda kegiatan Ormawa Y tersebut tidak sepenuhnya dapat didanai oleh universitas, seperti kegiatan ulang tahun Ormawa Y, rekreasi, dan kunjungan alumni. Meskipun dana Ormawa $\mathrm{Y}$ tidak hanya tergantung dari pendanaan universitas, terdapat upaya dari Ormawa Y untuk mendapatkan laba dari kegiatan yang didanai universitas, agar dana tersebut dapat digunakan untuk kegiatan Ormawa yang tidak didanai universitas. Ormawa berupaya mendapatkan laba tersebut dengan melakukan mark-up anggaran kegiatan.

Sedangkan persamaan titik-titik pressure terdiri dari:

1) Ketidakpastian

Pemalsuan tanda tangan presensi peserta dan panitia kegiatan Ormawa dilakukan oleh kedua 
Ormawa $\mathrm{Y}$ dan Ormawa $\mathrm{Z}$ untuk mendapatkan pencairan dana yang utuh sesuai anggaran yang sudah disetujui. Tanda tangan presensi palsu tersebut terkait dengan pengeluaran konsumsi peserta dan panitia acara. Dalam suatu kegiatan, pengurus Ormawa mengalami kesulitan untuk memastikan kehadiran seluruh undangan. Jika peserta dan panitia acara yang hadir lebih sedikit dari jumlah yang diundang, maka pengurus Ormawa akan melakukan tanda tangan presensi fiktif bagi yang tidak hadir.

2) Kerumitan administrasi pembuatan LPJ serta pendeknya rentang waktu penyelesaian LPJ dan SPJ yang diberikan oleh universitas/fakultas

Kerumitan penyusunan LPJ dan SPJ berhubungan dengan penentuan kriteria nota/kuitansi yang boleh dilampirkan dalam LPJ kegiatan Ormawa. Disamping itu, pengurus Ormawa tidak diperkenankan mengajukan proposal usulan kegiatan yang baru jika LPJ kegiatan yang sebelumnya belum selesai. Hal-hal tersebut menciptakan kreatifitas negatif pengurus Ormawa Y dan $\mathrm{Z}$ untuk memiliki nota kosong dan membuat stempel palsu.

3) Manajemen pengarsipan bukti transaksi yang tidak tertib

Pengurus Ormawa Y dan Ormawa Z memiliki kesamaan dalam hal kesibukan pribadi di luar organisasi yang berdampak pada pengarsipan bukti transaksi yang kurang tertib. Kondisi tersebut mengakibatkan hilangnya bukti transaksi seperti nota/kuitansi, yang kemudian diatasi oleh pengurus Ormawa Y dan Ormawa $Z$ dengan membuat sendiri nota/kuitansi palsu sebagai pengganti nota/kuitansi yang hilang kemudian dilengkapi dengan stempel palsu milik Ormawa.

Temuan penelitian menunjukkan bentuk tekanan yang beragam pada Ormawa. Tekanan bersifat organisasi yang berarti tekanan tersebut menimbulkan tindakan fraud yang untuk kepentingan Ormawa bukan demi kepentingan pribadi para pengurus. Ketakutan atau kekuatiran tidak tercapainya tujuan atau agenda organisasi merupakan tekanan dominan yang memunculkan fraud. Selain itu, latar belakang keuangan juga ditemukan hampir pada semua bentuk tekanan. Tekanan dalam hal keuangan dapat menimbulkan fraud laporan keuangan (Skousen et al., 2009).

\section{b. Kesempatan (Opportunity)}

Data wawancara dan observasi yang disajikan sebelumnya menunjukkan adanya unsur opportunity yang memberikan peluang bagi pengurus Ormawa untuk melakukan kecurangan. Unsur kesempatan tersebut meliputi:

1) Pengawasan yang lemah dari pihak yang terkait

Peran pendamping Ormawa Y dan Ormawa Z, peran petugas bagian kemahasiswaan, khususnya di tingkat universitas sehubungan dengan proses LPJ dan SPJ tergolong sangat rendah. Hal tersebut membuat pengurus Ormawa Y dan Ormawa Z secara bebas membuat LPJ yang didukung dengan dokumen transaksi fiktif. Selain itu, petugas yang berwenang untuk mengawasi dan memeriksa LPJ atas dasar kepercayaan memberikan kesempatan bagi pengurus Ormawa untuk melakukan kecurangan (Puspitasari et al., 2015).

2) Sanksi ringan untuk pelaku fraud

Sanksi yang ringan akan memberikan "pembelajaran" bagi pengurus Ormawa bahwa tidak masalah untuk melakukan fraud karena tidak menimbulkan dampak negatif yang memberikan efek jera bagi pengurus. "Pembelajaran" ini akan menimbulkan budaya organisasi pengurus Ormawa untuk semakin rapi dalam melakukan fraud. Sikap memaklumi atas pelaporan keuangan yang curang menjadi salah satu faktor para pelaku untuk melakukan kecurangan (Setiawan et al., 2013). Disamping itu, petugas LPJ enggan memeriksa detail bukti transaksi pengeluaran asli, namun petugas meminta pengurus Ormawa untuk menyediakan satu kuitansi fiktif untuk pengeluaran demi kemudahan pemeriksaan. Permintaan tersebut akan memberikan peluang bagi pengurus Ormawa untuk melakukan fraud dengan membuat sendiri nota palsu dan memberi stempel palsu. Sistem atau saran dari pihak universitas menciptakan kesempatan berbuat curang pengurus Ormawa (Puspitasari et al., 2015).

Temuan aspek peluang atau kesempatan di atas menunjukkan lemahnya pengendalian internal, tata kelola, dan peraturan pada tingkat fakultas dan universitas dalam bidang manajemen Ormawa. Kondisi tersebut menjadi bahan pertimbangan bagi para pengurus dalam mempelajari peluang yang ada. Pengendalian internal, tata kelola, lingkungan hokum, dan peraturan bertujuan untuk mengurangi kemungkinan dan dampak dari tindakan fraud (Trompeter et al., 2013). Masing-masing unsur tersebut berada di luar kendali pelaku fraud, namun memengaruhi penilaian pelaku fraud terhadap kemungkinan berhasil tidaknya dalam melakukan dan menyembunyikan tindakan fraud (Trompeter et al., 2013). Kesempatan memiliki pengaruh yang signifikan terhadap kecurangan pelaporan keuangan (Skousen et al., 2009). 


\section{c. Rasionalisasi (Rationalization)}

Penelitian ini menemukan beberapa jenis rasionalisasi pengurus Ormawa Y dan Ormawa $\mathrm{Z}$ untuk melakukan pembenaran atas praktik fraud dalam pelaporan keuangan. Jenis rasionalisasi tersebut adalah sebagai berikut:

1) Tradisi fraud yang turun menurun dan pemikiran "semua Ormawa juga melakukan" Praktik pelaporan keuangan (LPJ) di Ormawa Y dan Ormawa Z merupakan sebuah tradisi yang telah diwariskan secara turun-temurun oleh pengurus lama hingga pengurus saat ini. Hal ini sudah biasa dilakukan sejak lama dimana setiap pengurus menirukan tata cara penyusunan laporan pertanggungjawaban kepengurusan sebelumnya. Kebiasaan ini kemudian menjadi budaya Ormawa yang tidak bisa dilepaskan dari praktik pelaporan LPJ, seperti budaya stempel palsu dan nota palsu. Puspitasari et al. (2015) juga menemukan adanya tradisi atau kebiasaan yang dilakukan secara turun temurun dalam pembuatan LPJ yang mengarah pada fraud. Budaya birokrasi yang menyimpang dilakukan secara turun temurun oleh karyawan atau anggota dalam sebuah organisasi (Setiawan et al., 2013). Tradisi turun temurun untuk melakukan fraud pada Ormawa dengan pernyataan "semua Ormawa melakukannya" serupa dengan rasionalisasi yang digunakan masyarakat Amerika Serikat untuk membenarkan tindakan fraud "semua orang melakukannya" (Mayhew \& Murphy, 2014). Hal tersebut berarti pernyataan bahwa "semua orang melakukannya (fraud)" merupakan pernyataan rasionalisasi tindakan fraud yang menyebabkan pengurus Ormawa saat ini tidak merasa takut dan bersalah karena hal ini sudah lumrah untuk dilakukan.

2) Demi kepentingan organisasi

Pembenaran pengurus Ormawa $\mathrm{Y}$ dan Ormawa $\mathrm{Z}$ dalam praktik fraud penyusunan LPJ adalah frauddilakukan demi kepentingan organisasi. Kedua belah pihak Ormawa membenarkan tindakan fraud karena tanpa ada manipulasi LPJ maka Ormawa akan kesulitan dalam proses pencairan dana yang kemudian berdampak pada terhambatnya pelaksanaan kegiatan sesuai dengan program kerja. Dengan alasan kepentingan bersama (organisasi) tersebut, pengurus Ormawa berani melakukan praktik fraud. Hal ini sesuai dengan temuan Setiawan et al. (2013) bahwa rasionalisasi kecurangan adalah terkait dengan kesejahteraan pegawai (bersama). Kesalahan penyajian pelaporan yang disengaja dapat memberikan manfaat atau keuntungan bagi pengurus organisasi (Hamilton, 2016).

3) Penghematan uang (tabungan)

Ketidakpastian jumlah dana yang disetujui pihak kampus menyebabkan pengurus Ormawa Y dan Ormawa $\mathrm{Z}$ melakukan fraud untuk mendapatkan uang lebih atau uang sisa yang digunakan sebagai menyimpan uang (save money). Kegiatan save money dilakukan untuk mengantisipasi apabila pencairan dana dari kampus terlambat dan untuk berjaga-jaga apabila terjadi pengeluaran yang tidak terduga serta digunakan untuk pembiayaan program kerja lainnya. Temuan ini serupa dengan temuan Puspitasari et al. (2015) yang menyatakan bahwa ada praktik saving pada kasus kecurangan di penelitiannya yang digunakan pengurus Ormawa sebagai rasionalisasi tindakan fraud.

4) Anggaran dana Ormawa menjadi hak yang dimiliki Ormawa.

Anggaran yang diberikan dari pihak kampus bagi pengurus Ormawa dianggap menjadi hak Ormawa sehingga sisa uang program kerja menjadi hak Ormawa untuk digunakan. Klaim ini terjadi karena adanya pembenaran dari pengurus Ormawa terhadap pemanfaatan anggaran dana, sehingga terdapat anggapan jika uang tersebut berhak digunakan pengurus Ormawa selama digunakan untuk kepentingan bersama (Ormawa). Perasaan "berhak" untuk menggunakan dana yang sudah dianggarkan bagi kegiatan Ormawa adalah sebagai bentuk pembenaran atas fraud disebutkan oleh Free (2015) sebagai "bentuk pelaporan pertanggungjawaban hanya dialihkan". Pengurus Ormawa melakukan fraud tanpa ada rasa takut adalah karena penggunaan uang yang didapat dari anggaran dana Ormawa digunakan untuk belanja Ormawa namun bukti transaksi tersebut dialihkan. Hal ini dilakukan Ormawa karena terdapat beberapa belanja yang dikeluarkan pengurus Ormawa untuk pelaksanaan progam kerja namun belanja tersebut tidak dapat digunakan dalam LPJ. Dengan alasan ini, pengurus tidak merasa bersalah apabila dilakukan kecurangankecurangan pada pelaporan keuangan yang bersifat pengalihan bentuk pertanggungjawaban (nota berbeda dengan barang yang dibeli). Hal ini mendorong seseorang untuk mencari pos-pos pembiayaan lain yang memungkinkan pembelian tersebut. Sesuai dengan pernyataan tersebut, Puspitasari et al. (2015) menemukan adanya praktik penggunaan nota palsu dan stempel palsu yang digunakan pengurus Ormawa untuk melakukan kecurangan berupa belanja fiktif baik itu berupa mark-up atau pengalihan bukti belanja. Begitu juga dengan Setiawan et al. (2013) yang 
menemukan adanya praktik permainan angka dan nota fiktif dalam pelaporan keuangan suatu organisasi.

5) Sikap pengurus yang mendukung fraud

Pengurus Ormawa melakukan kecurangan dikarenakan sikap dari pegawai kampus yang bertanggung jawab atas Ormawa justru memberikan saran untuk melakukan kecurangan dengan menolak nota asli dan meminta nota palsu yang menyajikan jumlah nominal yang utuh sesuai dengan nilai di proposal untuk kemudahan pengecekan. Sikap pegawai tersebut menjadikan pengurus Ormawa memiliki alasan untuk melanjutkan tradisi fraud. Penelitian Setiawan et al. (2013) menemukan aktor pelaku kecurangan melakukan praktik fraudkarena tradisi yang diketahui bersama sebagai sebuah bentuk birokrasi kantor. Data penelitian ini menunjukkan beragam bentuk rasionalisasi yang terbentuk pada pengurus Ormawa untuk membenarkan tindakan penyimpangan yang dilakukan. Pada dasarnya, loyalitas pengurus pada Ormawa merupakan bentuk rasionalitas yang dominan ditemukan. Selain itu, terdapat budaya organisasi fakultas dan universitas yang mendukung terbentuknya anggapan wajar untuk melakukan penyimpangan pada para pengurus Ormawa. Budaya etika dan kepemimpinan organisasi dapat memengaruhi kemampuan manajemen untuk merasionalisasi dan melakukan kecurangan (Trompeter et al., 2013)

Temuan bentuk-bentuk rasionalisasi tindakan fraud pada Ormawa universitas negeri $\mathrm{X}$ memberikan kontribusi empiris karena masih terdapat sedikit penelitian yang berhubungan dengan rasionalisasi fraud (Hogan et al., 2008; Murphy, 2012). Hal tersebut dikarenakan masih sedikitnya penelitian akuntansi yang memberikan perhatian pada elemen rasionalisasi fraud (Murphy \& Dacin, 2011). Selain itu, temuan ini memberikan kontribusi secara praktis khususnya bagi pihak universitas dan fakultas, yaitu untuk dapat memahami sifat dasar pembenaran penipuan agar dapat merumuskan tindakan anti penipuan dengan benar (Free, 2015).

\section{d. Kemampuan (Competence)}

Analisis dengan elemen competence merupakan analisis pembeda dengan penelitian terdahulu yang dilakukan oleh Puspitasari et al. (2015) dan Setiawan et al. (2013). Berdasarkan data hasil wawancara dan observasi, penelitian ini mendapatkan beberapa kemampuan yang dimiliki pengurus dalam praktik fraud. Pengurus Ormawa Y dan Ormawa Z tidak memiliki perbedaan dalam hal kemampuan melakukan fraud. Berikut penjelasan mengenai kemampuan yang dimiliki pengurus Ormawa:

1) Kecerdasan menyusun LPJ rekayasa.

Pengurus Ormawa memiliki kemampuan dalam menyusun laporan keuangan. Kemampuan yang dimiliki ini adalah seperti mampu menyusun LPJ dan membuat bukti transaksi dengan rekayasa yang meyakinkan. Jika Ormawa tidak memiliki kemampuan dalam merekayasa LPJ, maka LPJ tidak akan dapat lolos sampai pada tahap validasi petugas dan tahap pencairan dana.

2) Keberanian dalam berbohong.

Kemampuan atau keberanian berbohong pengurus Ormawa juga menjadi alasan terjadinya praktik kecurangan dapat terjadi. Jika pengurus Ormawa tidak berani, maka pengurus Ormawa tidak akan membuat LPJ yang melibatkan kecurangan. Keberanian dalam hal ini mengarah ke kesengajaan pengurus dalam melakukan praktik kecurangan. Unsur kesengajaan untuk melakukan kebohongan merupakan karakteristik utama dari fraud (American Institute of Certified Public Accountants (AICPA), 2002; Hamilton, 2016).

3) Konsisten dalam melakukan kebohongan.

Konsisten dalam berbohong juga merupakan kemampuan yang dimiliki pengurus dalam melancarkan praktik kecurangan. Konsisten yang dimaksudkan seperti upaya untuk melakukan mark-up nilai pengeluaran di bukti transaksi. Contoh yang lain adalah pengurus Ormawa juga mampu membuat LPJ yang penuh manipulatif seperti nama panitia yang sudah tidak aktif dimasukkan ke dalam presensi panitia dan tanda tangan dimanipulasi oleh pengurus. Presensi fiktif biasanya dilakukan agar konsisten dengan jumlah anggaran konsumsi yang membutuhkan berkas. Konsisten dalam berbohong yang dilakukan pengurus Ormawa dapat dirumuskan dengan "satu kebohongan diikuti dengan kebohongan yang lain". Konsistensi dalam melakukan kebohongan akan menyebabkan kebohongan menjadi tidak terlihat dan dapat disamarkan.

4) Manajemen stress yang baik.

Data observasi menunjukkan bahwa pengurus Ormawa ketika menyerahkan LPJ yang cenderung fraud ke pihak kampus tidak terlihat takut dan gugup atau tidak menampakkan kepanikan dari 
raut muka. Kondisi tersebut terjadi karena bentuk fraud itu sudah biasa dilakukan. Manajemen stress yang dimiliki pengurus Ormawa juga merupakan kemampuan yang menjadi faktor keberhasilan praktik kecurangan LPJ Ormawa. Seseorang yang mengalami stress akan cenderung menunjukkan rasa takut, cemas, sulit berkonsentrasi dan mudah tersinggung (Lazarus \& Folkman, 1984). Masalah ini dapat diatasi karena pengurus Ormawa memiliki kemampuan mengendalikan stress. Pengurus dalam melakukan praktik kecurangan LPJ dapat mengatasi kendala-kendala yang dihadapi dengan mengedepankan berfikir secara rasional dan mampu mengatasi stress dari tekanan yang ada. Jika pengurus Ormawa tidak memiliki kemampuan dalam hal manajemen stress, maka LPJ tidak akan diselesaikan secara sempurna.

5) Kemampuan memaksa anggota.

Dalam praktik pelaporan LPJ Ormawa, pengurus memiliki kemampuan dalam memaksa anggota untuk mengikuti perintah. Contoh perintah adalah bendahara yang meminta anggota untuk selalu meminta nota kosong jika melakukan belanja barang di toko atau di warung. Contoh lain adalah ketika sekretaris meminta bantuan anggota untuk mengisi presensi dikarenakan adanya peserta tidak hadir. Kemampuan ini dimiliki pengurus karena kedudukan pengurus dalam sebuah organisasi. Adanya senioritas atau orang yang dituakan dalam organisasi menyebabkan anggota mengikuti perintah tersebut.

Temuan penelitian di atas menunjukkan bahwa competence atau capability para pengurus Ormawa memberikan kontribusi besar terjadinya fraud. Para pengurus Ormawa memiliki competence atau capability untuk mengetahui sebuah peluang dan memanfaatkan peluang tersebut untuk sering melakukan fraud. Fraud tidak akan terjadi tanpa orang yang tepat dengan kemampuan yang tepat (Abdullahi \& Mansor, 2015). Temuan ini tergolong memprihatinkan dikarenakan universitas dan fakultas menyediakan Ormawa sebagai sarana bagi mahasiswa untuk membentuk soft skills positif yang bermanfaat pada di dunia kerja namun pada kenyataannya membuat pengurus Ormawa melakukan fraud. Penelitian ini menunjukkan bahwa Ormawa digunakan oleh mahasiswa sebagai tempat untuk menerapkan competence yang bersifat negatif dan akhirnya mendukung terbentuknya tindakan fraud.

\section{e. Arogansi (Arrogance)}

Arogansi yang dimiliki pengurus Ormawa berdasarkan analisis data adalah sikap yang ambisius dalam menetapkan atau mencapai target pengumpulan dana dan keserakahan untuk memaksimalkan anggaran yang diterima dari pihak kampus.

1) Ambisius mencapai target.

Data menunjukkan bahwa pengurus Ormawa Y memiliki ambisi yang tinggi dalam menetapkan target keuangan yaitu sebesar Rp11.000.000 dimana angka ini naik Rp3.000.000 dari target tahun sebelumnya. Ambisi yang besar ini menunjukkan arogansi pengurus Ormawa yang menyebabkan terjadinya fraud pada pelaporan LPJ Ormawa Y. Pengurus Ormawa menetapkan target yang terlalu tinggi dibandingkan pengurus-pengurus sebelumnya. Ambisi tersebut menimbulkan tekanan bagi pengurus Ormawa yang pada akhirnya pengurus Ormawa menghalalkan berbagai macam cara untuk mencapai ambisi tersebut. Sedangkan Ormawa Z tidak memiliki ambisi mencapai target keugangan, namun Ormawa Z hanya memiliki target keberhasilan program kerja. Meskipun demikian, adanya target program kerja juga menjadi ambisi Ormawa yang menyebabkan Ormawa melakukan kecurangan.

2) Serakah untuk memaksimalkan anggaran.

Keserakahan dalam memaksimalkan dana yang didapat dari universitas juga merupakan bentuk sikap arogansi pengurus Ormawa dalam melaksanakan praktik kecurangan LPJ. Pengurus kedua Ormawa sama-sama memiliki pola pikir yang sama yaitu "eman" atau "sayang sekal" jika dana tidak dioptimalkan. Keserakahan ini menyebabkan pengurus Ormawa melakukan berbagai macam praktik kecurangan pelaporan LPJ dengan melakukan mark-up anggaran dan membuat nota fiktif. Data penelitian ini menunjukkan bahwa arogansi dan keserakahan pengurus Ormawa berperan dalam timbulnya tindakan fraud pada Ormawa. Temuan ini serupa dengan studi yang dilakukan oleh Committee of Sponsoring Organisasi dari Treadway Commission (COSO) yang menemukan bahwa sebesar $70 \%$ penipu memiliki profil yang menggabungkan tekanan dengan kesombongan atau keserakahan (Marks \& Jonathan, 2012). Keserakahan merupakan bagian dari tekanan keuangan pribadi yang berkaitan dengan motivasi karyawan untuk melakukan penipuan (Rae \& Subramaniam, 2008). 
Temuan penelitian ini memberikan wawasan bagi pihak fakultas dan universitas mengenai perlunya pendampingan yang lebih intensif bagi pengurus Ormawa dari dosen pendamping kegiatan kemahasiswaan. Pendampingan tersebut bertujuan memberikan arahan dalam menetapkan target keuangan dan program kerja Ormawa yang lebih rasional sehingga sifat ambisi tidak menyebabkan tekanan yang dapat memunculkan tindakan fraud.

\section{SIMPULAN}

Teori Fraud Pentagon memberikan pemahaman yang lebih mendalam mengenai penyebab dan ukuran pencegahan untuk tindakan fraud (Avortri \& Agbanyo, 2020). Penelitian ini menemukan kondisi bahwa pengurus Ormawa X dan Ormawa Y di Unviersitas X melakukan berbagai bentuk kecurangan seperti membuat nota palsu, stempel palsu, dan tanda tangan palsu. Timbulnya praktik fraud pada Ormawa disebabkan karena adanya tekanan dari internal dan eksternal organsiasi dimana tekanan dari pihak eksternal menjadi faktor yang dominan dalam penelitian ini. Kondisi yang cukup memprihatinkan dari praktik fraud Ormawa adalah praktik tersebut sudah menjadi budaya selama bertahun-tahun dari para pengurus senior yang kemudian memberikan contoh kepada pengurus junior. Selain itu, praktik tersebut sudah biasa ditemukan di hampir semua Ormawa sehingga tindakan fraud tergolong praktik yang dapat ditoleransi. Beberapa penyebab praktik fraud pada Ormawa memberikan wawasan pada pihak fakultas dan universitas untuk menentukan tindakan-tindakan pencegahan yang diperlukan, seperti peningkatan pengendalian internal sehubungan dengan LPJ Ormawa.

Penelitian ini dapat memberikan kontribusi pada pihak fakultas atau universitas untuk menganalisis setiap proses kegiatan Ormawa mulai dari penyusunan program kerja sampai dengan tahap pertanggungjawaban. Hasil analisis tersebut diharapkan dapat berlanjut ke pemberian arahan atau pedoman yang tidak memberikan peluang bagi Ormawa untuk melakukan fraud. Pedoman juga termasuk prosedur pembimbingan oleh dosen pembina Ormawa serta syarat-syarat LPJ dan SPJ yang efektif dan efisien. Selain itu, pendidikan etika dan moralitas perlu diberikan oleh pihak universitas/ fakultas kepada para pengurus Ormawa

Penelitian ini memiliki beberapa keterbatasan. Keterbatasan pertama adalah adanya kemungkinan ketidakjujuran informan dalam menjawab pertanyaan peneliti. Keterbatasan kedua berhubungan dengan pergantian pengurus Ormawa yang dapat menimbulkan ketidaklengkapan informasi yang diperoleh dalam penelitian ini. Hal ini dikarenakan pengalaman dan pengetahuan pengurus baru tergolong minim. Keterbatasan ketiga adalah penelitian ini hanya difokuskan pada dua Ormawa pada universitas negeri yang sama. Keterbatasan terakhir dalam penelitian ini adalah belum melibatkan informan level tinggi di struktur organisasi fakultas (wakil dekan) atau universitas (wakil rektor) bidang kemahasiswaan. Dengan keterbatasan tersebut, penelitian selanjutnya dapat melakukan beberapa pengembangan dari penelitian ini. Penelitian selanjutnya diharapkan dapat melakukan penelitian di beberapa Ormawa pada universitas yang berbeda, karena setiap universitas memiliki kebijakan manajemen Ormawa yang berbeda. Penelitian selanjutnya juga diharapkan dapat menambahkan wakil dekan dan wakil rektor bidang kemahasiswaan sebagai informan penelitian untuk mendapatkan gambaran yang lengkap terkait dengan praktik yang dilakukan oleh Ormawa.

\section{DAFTAR RUJUKAN}

Abdullahi, R., \& Mansor, N. (2015). Fraud triangle Theory and Fraud Diamond Theory. Understanding The Convergent and Divergent for Future Research. International Journal of Academic Research in Accounting, Finance, and Management Sciences, 54), 38-45. doi:10.6007/IJARAFMS/v53/1823.

American Institute of Certified Public Accountants (AICPA). (2002). Consideration of Fraud In A Financial Statement Audit. Statement on Auditing Standards No. 99. AICPA.

Avortri, C., \& Agbanyo, R. (2020). Determinants of Management Fraud in The Banking Sector of Ghana: The Perspective of The Diamond Fraud Theory. Journal of Financial Crime, 17 July 2020. doi:10.1108/JFC-06-2020-0102.

Danuta, K. S. (2017). Crowe's Fraud pentagon theorydalam Pencegahan Fraud pada Proses Pengadaan melalui E-Procurement. Jurnal Kajian Akuntansi, 1(2), 161-171. doi:10.33603/jka.v1i2.826.

Free, C. (2015). Looking through The Fraud triangle: A Review and Call for New Directions. Meditari Accountancy Research, 23(2), 175-196. doi:10.1108/MEDAR-02-2015-0009. 
Hamilton, E. (2016). Evaluating The Intentionality of Identified Misstatements: How Perspective Can Help Auditors in Distinguishing Errors From Fraud. Auditing: A Journal of Practice \& Theory, 35(4), 57-78. doi:10.2308/ajpt-51452.

Hogan, C., Rezaee, Z., Riley, R., \& Velury, U. (2008). Financial Statement Fraud: Insights from The Academic Liteature. Auditing: A Journal of Practice and Theory, 27(2), 231-252. doi:10.2308/ aud.2008.27.2.231.

Karyono. (2013). Forensik Fraud. Yogyakarta: Andi Offset.

Lazarus, R. S., \& Folkman, S. (1984). Stress, Appraisal, and Coping: New York: Springer.

Marks, \& Jonathan. (2012). The Mind Behind The Fraudsters Crime: Key Behavioral and Environmental Elements. Chicago: Crowe Horwarth LLP.

Mayhew, B., \& Murphy, P. (2014). The Impact of Authority on Reporting Behavior, Rationalization and Affect. Contemporary Accounting Research, 31(2), 420-443. doi:10.1111/1911-3846.12037.

Miles, M. B., \& Huberman, A. . (1992). Analisis Data Kualitatif: Buku Sumber tentang MetodeMetode Baru. Jakarta: Universitas Indonesia.

Moleong, L. J. (2004). Metode Penelitian Kualitatif. Bandung: PT. Remaja Rosdakarya.

Muhsin, M., Kardoyo, M., \& Nurkhin, A. (2018). What Determinants of Academic Fraud Behavior? from Fraud triangle to Fraud Pentagon Perspective. International Conference on Economics, Business and Economic Education, 3(10), 154-167. doi:10.18502/kss.v3i10.3126.

Murphy, P. (2012). Attitude, Machiavellianism and The Rationaliation of Misreporting. Accounting; Organizations and Society., 37(4), 242-259. doi:10.1016/j.aos.2012.04.002.

Murphy, P., \& Dacin, M. T. (2011). Psychological Pathways to Fraud: Understanding and Preventing Fraud in Organisations. Journal of Business Ethics, 101(4), 601-618. doi:10.1007/s10551-0110741-0.

Puspitasari, Ragil, Y., Haryadi, B., \& Setiawan, A. R. (2015). Sisi Remang Pengelolaan Keuangan Organisasi Mahasiswa. Jurnal Akuntansi Multiparadigma, 6(1), 133-144, doi:10.18202/ jamal.2015.04.6001.

Rae, K., \& Subramaniam, N. (2008). Quality of Internal Control Procedures: Antecedents and Moderating Effect on Organisational Justice and Employee Fraud. Managerial Auditing Journal, 23(2), 104-124. doi:10.1108/02686900810839820.

Salsabil, Mutiara, S., Utami, I., \& Hapsari, A. N. S. (2019). Fraud dan Whistleblowing: Tinjauan Pengelolaan Dana Organisasi Kemahasiswaan. Universitas Kristen Satya Wacana: Junal Akuntansi Bisnis, 12(1), 64-76.

Setiawan, Redy, A., Irianto, G., \& Achsin, M. (2013). System-Driven (n)Fraud: Tafsir Aparatur terhadap "Sisi Gelap” Pengelolaan Keuangan Daerah. Jurnal Akuntansi Multiparadigma, 4(1), 85-100. doi:10.18202/jamal.2013.04.7184.

Skousen, C. J., Smith, K. R., \& Wright, C. J. (2009). Detecting and Predicting Financial Statement Fraud: The Effectiveness of The Fraud triangle And SAS No. 99. Advance In Financial Economic, 13, 58-81. doi:10.1108/S1569-3732(2009)0000013005.

Tiffani, Laila, \& Marfuah. (2015). Deteksi Financial Statement Fraud dengan Analisis Fraud triangle pada Perusahaan Manufaktur yang Terdaftar di Bursa Efek Indonesia. Jurnal Akuntansi dan Audit Indonesia, 19(2), 122-125. doi:10.20885/jaai.vol19.iss2.art3

Trompeter, G., Carpenter, T., Desai, N., Jones, K., \& Riley, D. (2013). A Synthesis of Fraud-Related Research. Auditing. A Journal of Practice and Theory, 32(1), 287-321. doi:10.2308/ajpt-50360.

Wolfe, D., \& Hermanson, D. (2004). The Fraud Diamond: Considering the Four Elements of Fraud. CPA Journal, 12(Exhibit 1), 1-5.

Yin, R. K. (2009). Studi Kasus: Desain dan Metode. Jakarta: PT. Rajagrafindo Persada. 
Halaman ini sengaja dibiarkan kosong 